\title{
Picomole per Liter
}

National Cancer Institute

\section{Source}

National Cancer Institute. Picomole per Liter. NCI Thesaurus. Code C67434.

A unit of concentration (molarity unit) equal to one trillionth of a mole (10E-12 mole) per one liter of solution. 